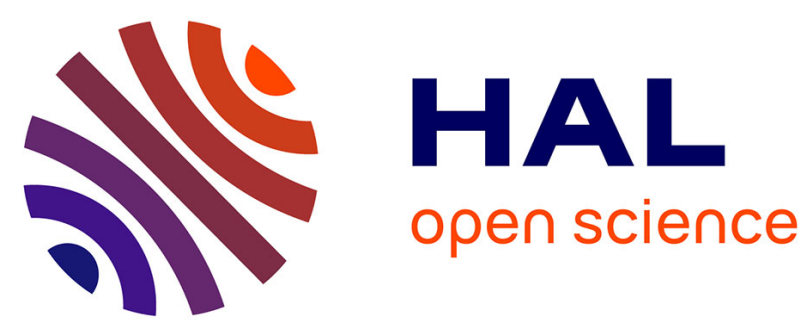

\title{
Monitoring atmospheric levels and deposition of dioxin-like pollutants in sub-alpine Northern Italy
}

Javier Castro-Jiménez, S J Eisenreich, G. Mariani, H. Skejo, G. Umlauf

\section{To cite this version:}

Javier Castro-Jiménez, S J Eisenreich, G. Mariani, H. Skejo, G. Umlauf. Monitoring atmospheric levels and deposition of dioxin-like pollutants in sub-alpine Northern Italy. Atmospheric Environment, 2012, 56, pp.194-202. 10.1016/j.atmosenv.2012.03.081 . hal-02080851

\section{HAL Id: hal-02080851 https://hal.science/hal-02080851}

Submitted on 27 Mar 2019

HAL is a multi-disciplinary open access archive for the deposit and dissemination of scientific research documents, whether they are published or not. The documents may come from teaching and research institutions in France or abroad, or from public or private research centers.
L'archive ouverte pluridisciplinaire $\mathbf{H A L}$, est destinée au dépôt et à la diffusion de documents scientifiques de niveau recherche, publiés ou non, émanant des établissements d'enseignement et de recherche français ou étrangers, des laboratoires publics ou privés. 

Atmospheric Environment 56 (2012) 194-202. doi:10.1016/j.atmosenv.2012.03.081

\title{
Monitoring atmospheric levels and deposition of dioxin-like pollutants in sub-alpine Northern Italy
}

\author{
J. Castro-Jiménez ${ }^{\text {a,* }}$, S.J. Eisenreich ${ }^{\mathrm{b}}$, G. Mariani ${ }^{\mathrm{c}}$, H. Skejo $^{\mathrm{c}}$, G. Umlauf ${ }^{\mathrm{c}}$ \\ ${ }^{a}$ Department of Environmental Chemistry, Institute of Environmental Assessment and Water Research (IDAEA-CSIC), Barcelona, Spain \\ ${ }^{\mathrm{b}}$ European Commission-Joint Research Centre, Directorate of Science Policy, Brussels, Belgium \\ ${ }^{\mathrm{c}}$ European Commission-Joint Research Centre, Institute for Environment and Sustainability, Ispra, Italy
}

\section{A R T I C L E I N F O}

\section{Article history:}

Received 19 December 2011

Received in revised form

28 March 2012

Accepted 29 March 2012

\section{Keywords:}

PCDD/Fs

DL-PCBs

Deposition fluxes

Air concentration

Lake Maggiore

Environmental exposure

\begin{abstract}
A B S T R A C T
The objective of this work was to assess the atmospheric occurrence, seasonal variations and deposition of dioxin-like pollutants (17 PCDD/Fs + 12 DL-PCBs) in sub-alpine northern Italy. A total of 108 weekly integrated samples (aerosol + gas phases) were collected during a 1-year period (2005-2006) at the Ispra EMEP site (Northern Italy, $45^{\circ} 49^{\prime} \mathrm{N}, 8^{\circ} 38^{\prime} \mathrm{E}$ ). Atmospheric loadings into Lake Maggiore were also estimated by implementing a deposition model. $\sum 2,3,7,8-\mathrm{PCDD} / \mathrm{F}$ atmospheric total concentrations were dominated by the aerosol-bound fraction which ranged from 50 to 3080 (1-215 $\mathrm{WHO}_{98}$ TEQ) fg m ${ }^{-3}$. In contrast DL-PCB levels were dominated by the gas phase concentrations and varied from 1800 to 14800 (1-5 $\left.\mathrm{WHO}_{98} \mathrm{TEQ}\right) \mathrm{fg} \mathrm{m}^{-3}$. The aerosol and gas phase concentrations of PCDD/Fs and DL-PCBs exhibited a similar seasonality (higher values in winter time for aerosol-bound contaminants and lower concentrations for gas phase contaminants) in spite of their different environmental sources and properties. Estimated total atmospheric (dry + wet) depositional fluxes of dioxin-like pollutants in sub-alpine northern Italy were $\sim 0.2-\sim 9.5 \mathrm{ng} \mathrm{m}^{-2} \mathrm{~d}^{-1}$, with wet deposition dominating. Total atmospheric inputs $(2,3,7,8-\mathrm{PCDD} / \mathrm{Fs}+\mathrm{DL}-\mathrm{PCBs})$ into Lake Maggiore ranged from 14 to $304 \mathrm{~g} \mathrm{y}^{-1}$. Higher environmental concentrations of dioxin-like pollutants in sub-alpine northern Italy are expected in the cold season and in rainy days due to a combined effect of stagnant atmospheric conditions (low winds), household wood burning in the region and higher pollutant loads via rainfall in winter.
\end{abstract}

\section{Introduction}

Polychlorinated dibenzo-p-dioxins and dibenzofurans (PCDD/ Fs) and polychlorinated biphenyls (PCBs) are two families of persistent organic pollutants (POPs). Among the $419 \mathrm{PCDD} / \mathrm{F}+\mathrm{PCB}$ possible congeners, seventeen $\mathrm{PCDD} / \mathrm{Fs}$ (2,3,7,8-chlorine substituted) and twelve PCBs (DL-PCBs) (CBs-81, -77, -105, -114, $-118,-123,-126,-156,-157,-167,-169,-189)$, are considered dioxinlike pollutants, and of particular concern due to their accumulation and toxic effects in biota and humans (Safe, 1984, 1990; Van den Berg et al., 1998; Partzefall, 2002). Although PCBs have been removed from active use in nearly all countries since the mid1970 s, and primary (combustion) sources of PCDD/Fs are closely controlled (Lohmann et al., 2007), concerns regarding their global distribution and current ambient levels (human exposure) due to their high toxicity even at low levels remain. PCDD/Fs occur in the

\footnotetext{
* Corresponding author. Tel.: +34934006169.

E-mail addresses: javier.castro-jimenez@idaea.csic.es, jvcastrojm@gmail.com (J. Castro-Jiménez).
}

environment as unintentional byproducts of chemical manufacturing and incineration processes (Harrad and Jones, 1992; Bruzy and Hites, 1996) whereas, current emissions of PCBs derive from urban/industrial centers, landfills, open burning of products containing PCBs, waste incinerations, accidental fires and revolatilization from environmental reservoirs (Cousins and Jones, 1998; Breivik et al., 2002). After emission to the atmosphere, these contaminants participate in atmospheric processes that determine their inputs to environmental surfaces (e.g. waters, soils, vegetation) and their atmospheric transport (Wania and Mackay, 1996; Lohmann et al., 1999). Various regional or global monitoring networks/programs (e.g. TOMPs, UK; AMAP, Arctic region; EMEP in EU; IADN in North America, and GAPS, at global scale) have established ambient levels, deposition/transport and in some cases identify spatial-temporal trends of POPs (Blanchard et al., 2008; Pozo et al., 2009; Gioia et al., 2009, Aas and Breivik, 2010; Hung et al., 2010). PCDD/Fs and DL-PCB are infrequently included in monitoring programs, due to the difficulties in sampling and analyses at trace or ultra-trace levels and the associated high economic cost. As a result, there are many "non monitored areas" as well as little information on dioxin-like compound ambient 
concentrations. For instance, South-Western Europe remains largely uncovered by the EMEP POPs monitoring network (Fig. S1, supplementary material (SM)).

The objective of this work was to assess the atmospheric concentrations, seasonal variations and deposition of dioxin-like pollutants in a sub-alpine area of northern Italy as well as to quantify the atmospheric loading into neighboring Lake Maggiore. To achieve this goal, a monitoring and research station was established at the Joint Research Center (JRC) Ispra EMEP site in northern Italy near Lake Maggiore (Fig. 1). PCB (non-DL) atmospheric concentrations and deposition fluxes over one year and a limited data set (short-term sampling campaign) on PCDD/F and DL-PCB concentrations in air and bulk deposition have been reported for this site (Castro-Jiménez et al., 2008, 2009). PCDD/Fs have been reported in the Milan area and two other regions in northern Italy (i.e. Piemonte and Trieste) with a focus on urban and industrial impacted sites (Fattore et al., 2003; Colombo et al., 2009; Onofrio et al., 2011). However, no long-term study on dioxin-like pollutants has ever been conducted in the studied area.

\section{Experimental}

\subsection{Sampling location description}

Air samples were collected at the EMEP monitoring and research station at the JRC Ispra Site, north Italy (Fig. 1). A detailed description of the area has been published elsewhere (CastroJiménez et al., 2009).

\subsection{Air sampling}

Sampling strategy and methodology have been detailed in Castro-Jiménez et al. (2009). Briefly, integrated weekly air samples were collected from April 2005 to April 2006 using high volume samplers according to the U.S. EPA TO-9A Method (US EPA, 1999a). Two identical samplers were used interchangeably and 108 samples (54 aerosol +54 gas phase) were collected during the sampling period $\left(860 \pm 27 \mathrm{~m}^{3}\right.$ average sample volume). Quartz fiber filters (QFFs) were used for the collection of the particle air phase whereas polyurethane foam (PUF) was employed for the gas phase. Table S1 (SM) shows sampling details together with the meteorological parameters for each sampling event.

\subsection{Analytical determination}

QFFs and PUFs were Soxhlet extracted separately with nhexane/acetone $(220: 30 \mathrm{v} / \mathrm{v})$ for $48 \mathrm{~h}$ after being spiked with ${ }^{13} \mathrm{C}$ labelled DL-PCB and PCDD/Fs internal standards. Extract purification was executed with an automated clean-up system (PowerPrep). This method, previously used in our laboratory, has proven a high quality purification of the studied POPs (Castro-Jiménez et al., 2008). Two fractions were collected: one containing monoortho PCBs, and one containing non-ortho PCBs and PCDD/Fs. Purified extracts were evaporated to $\sim 0.5 \mathrm{ml}$ by using a TurboVap and then to dryness under gentle nitrogen flow. Prior to injection, $30 \mu \mathrm{L}$ of a toluene solution containing syringe ${ }^{13} \mathrm{C}$-labelled standards (PCBs 111, -170 and 1,2,3,4-TCDD and 1,2,3,7,8,9-HxCDD)

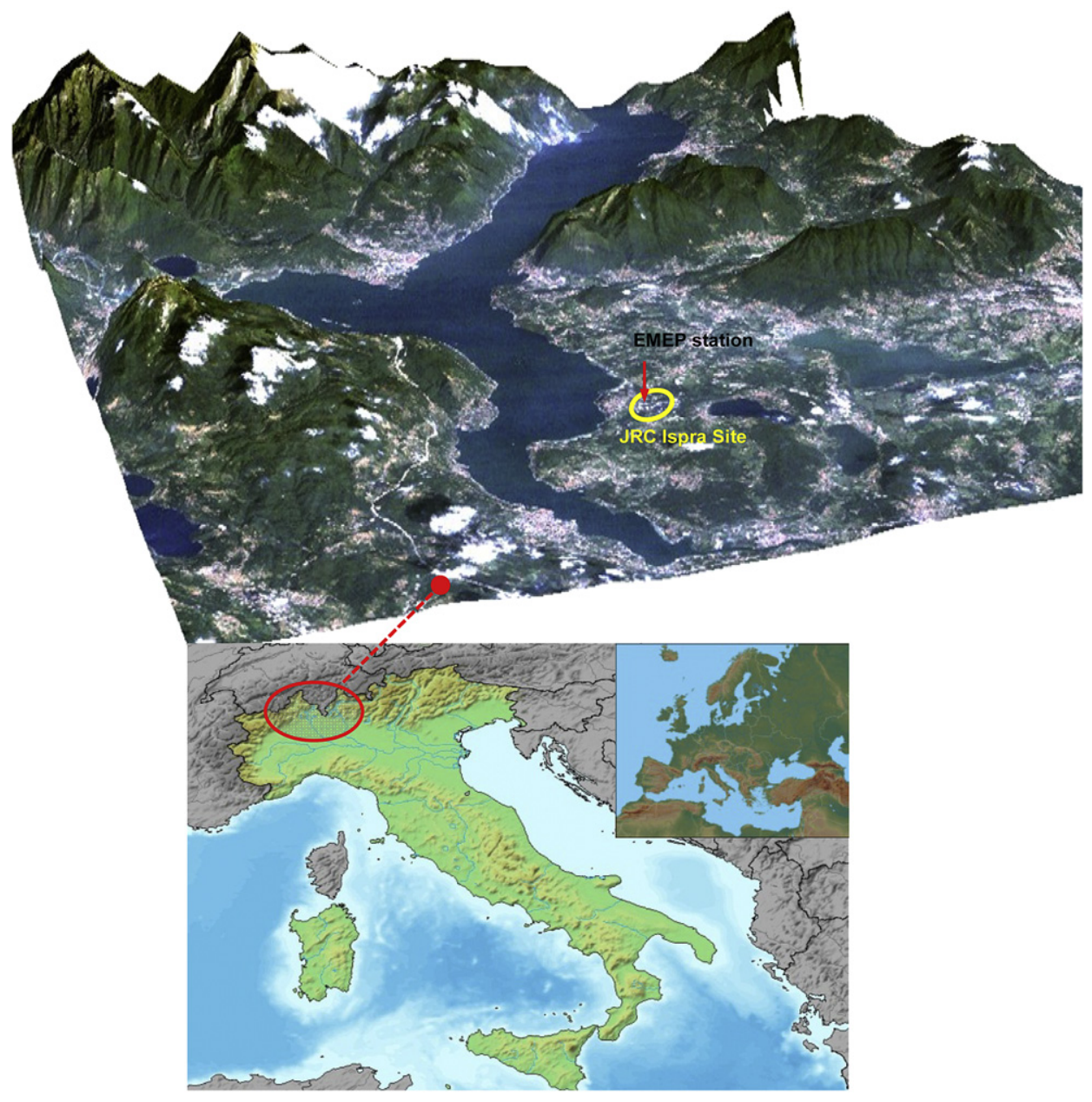

Fig. 1. Sampling site location close to Lake Maggiore (Northern Italy). 
were added to the fractions to determine the recoveries of the internal standards. Analysis of PCDD/Fs and PCB was performed according to EPA1613 and EPA (US EPA, 1994, 1999b). All organic solvents were dioxin analysis grade. Analysis of (1) mono-ortho PCBs and (2) non-ortho PCBs and PCDD/Fs was performed by two different couplings of high-resolution gas chromatograph (HRGC) high-resolution mass spectrometer (HRMS). A HT-8 and BP-DXN capillary columns, both $60 \mathrm{~m}$ long, $0.25 \mathrm{~mm}$ i.d. (inner diameter) and $0.25 \mu \mathrm{m}$ film were used, respectively (see Text S1 in SM for instrument details and GC and MS operating conditions).

\subsection{Quality assurance/quality control}

The QA/QC procedures followed are detailed in supporting information (Text S2, SM). Summarizing, field and procedural blanks were regularly collected and analyzed together with the samples. Blank values were at method detection limit (MDL) levels so concentrations reported were not corrected for blanks. MDL were calculated on the basis of a signal to noise ratio of $3 / 1$ in real samples (therefore taking into account the matrix effect and the influence of both processing and analytical steps). MDL values ranged from 1 to 38 and from 0.03 to $2.3 \mathrm{fg} \mathrm{m}^{-3}$ for DL-PCBs and $\mathrm{PCDD} / \mathrm{Fs}$, respectively, depending on the congener and the sample. Breakthrough was evaluated during the sampling campaign and results indicated that this artifact was not significant under the field conditions encountered. Sampling reproducibility was assessed by operating two samplers (A and B) simultaneously in selected sample events. The relative standard deviation (RSD) varied from 1 to $24 \%$ when comparing $\sum \mathrm{PCDD} / \mathrm{F}$ and $\sum \mathrm{DL}-\mathrm{PCB}$ results in the samples gathered simultaneously, except for only one sample which showed a higher variability ( $\sim 40 \%)$ but only for the DL-PCBs (Table S2, SM). Standards (natives $+{ }^{13} \mathrm{C}$-compounds) were introduced in the chromatographic sequence to evaluate possible variations during the time of analyses. Chromatographic peaks of target compounds were only considered when complying with the following QA/QC criteria: (1) the retention time of target compound were \pm 3 s of those observed for the corresponding standards; (2) experimental isotopic ratio of natives compounds were within $\pm 20 \%$ of the theoretical ratio and (3) peaks were at least 3 times higher than the noise. Average method recoveries ranged from $24 \pm 5$ to $58 \pm 7 \%$ and from $46 \pm 7$ to $87 \pm 11 \%$ for DL-PCB and $\mathrm{PCDD} / \mathrm{Fs}$ depending on the congener and the sample. Results were corrected by recoveries (isotopic dilution method).

\subsection{Calculating atmospheric deposition}

Atmospheric deposition was considered to be represented by the wet and dry deposition fluxes. Gaseous deposition (air to water flux) was not including in the calculation due to the lack of PCB and $\mathrm{PCDD} / \mathrm{Fs}$ concentration data in the receptor surfaces. Deposition fluxes may be therefore underestimated for those chemicals with a significant gaseous fraction.

\subsubsection{Dry deposition flux}

The dry deposition flux $\left(F_{\mathrm{DD}}, \mathrm{pg} \mathrm{m}^{-2} \mathrm{~d}^{-1}\right)$ was estimated from the particle deposition velocity, $V_{d}\left(\mathrm{~m} \mathrm{~d}^{-1}\right)$, and the PCDD/F and PCB concentrations in the aerosol phase $\left(C_{a}, \mathrm{pg} \mathrm{m}^{-3}\right)$ as:

$F_{\mathrm{DD}}=C_{a} V_{d}$

Particle deposition velocity depends on aerosol size distribution and atmospheric turbulence, which is influenced by wind speed. Deposition velocities of $0.2 \mathrm{~cm} \mathrm{~s}^{-1}$ have been reported for lake environments (Schottler and Eisenreich, 1997) and those varying from 0.39 to $0.52 \mathrm{~cm} \mathrm{~s}^{-1}$ for rural areas (Shih et al., 2006). In our model, we assumed an average deposition velocity of $0.4 \mathrm{~cm} \mathrm{~s}^{-1}$ which was considered representative for a lake environment located in a rural/semi-rural area. A degree of uncertainty (factor of $2-3$ ) is assumed due to the lack of measurements of $V_{d}$ during the 1-year sampling campaign.

\subsubsection{Wet deposition flux}

The wet deposition flux ( $F_{\mathrm{WD}}, \mathrm{pg} \mathrm{m}^{-2} \mathrm{~d}^{-1}$ ) was calculated as the product of the precipitation rate $P_{o}\left(\mathrm{~m}^{3} \mathrm{~m}^{-2} \mathrm{~d}^{-1}\right)$ and the contaminant concentration in rain water $C_{r}\left(\mathrm{pg} \mathrm{m}^{-3}\right)$ that includes both the atmospheric gas and particle phase contributions:

$F_{\mathrm{WD}}=C_{r} P_{o}$

Contaminant concentrations in precipitation as the result of the scavenging of the atmospheric gas phase by rain drops $\left(C_{\mathrm{rw}}\right)$ was calculated using the dimensionless Henry' law constant $\left(H^{\prime}=H / R T\right)$ and the measured gas phase concentrations. Henry' law constants $(H)$ values for PCB (Bamford et al., 2002) were corrected by temperature using Eq. (3):

$\operatorname{Ln}\left(\frac{H_{T}}{H}\right)=\frac{\Delta H}{R}\left(\frac{1}{T}-\frac{1}{T_{T}}\right)$

Where $H_{T}$ and $H$ are the Henry' law constants $\left(\mathrm{Pa} \mathrm{m}^{3} \mathrm{~mol}^{-1}\right)$ at the sampling average temperature $\left(T_{T}\right)$ and at standard temperature $(T$, $\left.298.15^{\circ} \mathrm{K}\right), \Delta H\left(\mathrm{~kJ} \mathrm{~mol}^{-1}\right)$ is the phase transition enthalpy of the compound and $R\left(\mathrm{~kJ}^{\circ} \mathrm{K}^{-1} \mathrm{~mol}^{-1}\right)$ is the gas constant. The correlation of $H$ with temperature proposed by Paasivirta et al. (1999) was used for PCDD/Fs. The scavenging of the aerosol by rain was calculated by multiplying the aerosol concentrations $\left(C_{a}\right)$ by the particle phase washout ratio $\left(W_{p}\right)$, so Eq. (2) becomes:

$F_{\mathrm{WD}}=\left(\frac{C_{g}}{H \prime}+W_{P} C_{a}\right) P_{o}$

The value of $W_{P}=2 \cdot 10^{5}$ was selected for our calculations, consistent with McLachlan and Sellström (2009), Jurado et al. (2005), and Dueri et al. (2010).

\section{Results and discussion}

\subsection{Ambient levels and seasonality}

Figs. 2 and 3 show the $\sum 2,3,7,8-P C D D / F s$ and $\sum D L-P C B s$ concentrations, respectively, in the atmospheric boundary layer aerosol (particle) and gas phases along the 1-year sampling period. Concentrations expressed as $\mathrm{WHO}_{98}$ TEQ are also provided for comparative purposes. Single congener and homologue series $\left(\sum \mathrm{Cl}_{4-8} \mathrm{DD} / \mathrm{F}\right)$ concentrations in the case of dioxins are provided in Tables S3-S6 (SM). Atmospheric concentrations of $\sum 2,3,7,8-\mathrm{PCDD} /$ $\mathrm{F}$ and $\sum \mathrm{Cl}_{4-8} \mathrm{DD} / \mathrm{F}$ were dominated by the aerosol-bound fraction, levels ranging from 50 to $3080\left(1-215 \mathrm{WHO}_{98} \mathrm{TEQ}\right) \mathrm{fg} \mathrm{m}^{-3}$ and from 90 to $9500 \mathrm{fg} \mathrm{m}^{-3}$, respectively (Fig. 2A, Table S3). Gas phase concentrations were lower and less variable, ranging from 12 to 67 (2-10 WHO $_{98}$ TEQ) fg m $\mathrm{m}^{-3}$ and from 200 to $910 \mathrm{fg} \mathrm{m}^{-3}$ for $\sum 2,3,7,8-\mathrm{PCDD} / \mathrm{Fs}$ and $\sum \mathrm{Cl}_{4-8} \mathrm{DD} / \mathrm{Fs}$, respectively (Fig. 2B, Table S4). Contrary to PCDD/Fs, DL-PCB atmospheric levels were dominated by gas phase concentrations ranging from 1800 to 14800 (1-5 $\mathrm{WHO}_{98}$ TEQ) fg $\mathrm{m}^{-3}$ (Fig. 3B, Table S5). Aerosol phase concentrations varied from 410 to $7800\left(0.1-15 \mathrm{WHO}_{98}\right.$ TEQ) $\mathrm{fg} \mathrm{m}^{-3}$ (Fig. 3A, Table S6).

Total $\mathrm{WHO}_{98}$ TEQ levels were dominated by the PCDD/F contribution, in particular in winter months (Figs. 2 and 3 , Tables S3-S6, SM). Total PCDD/F TEQ was dominated by 2,3,4,7,8PeCDF and 1,2,3,7,8-PeCDD accounting for the $37 \pm 4 \%$ and 


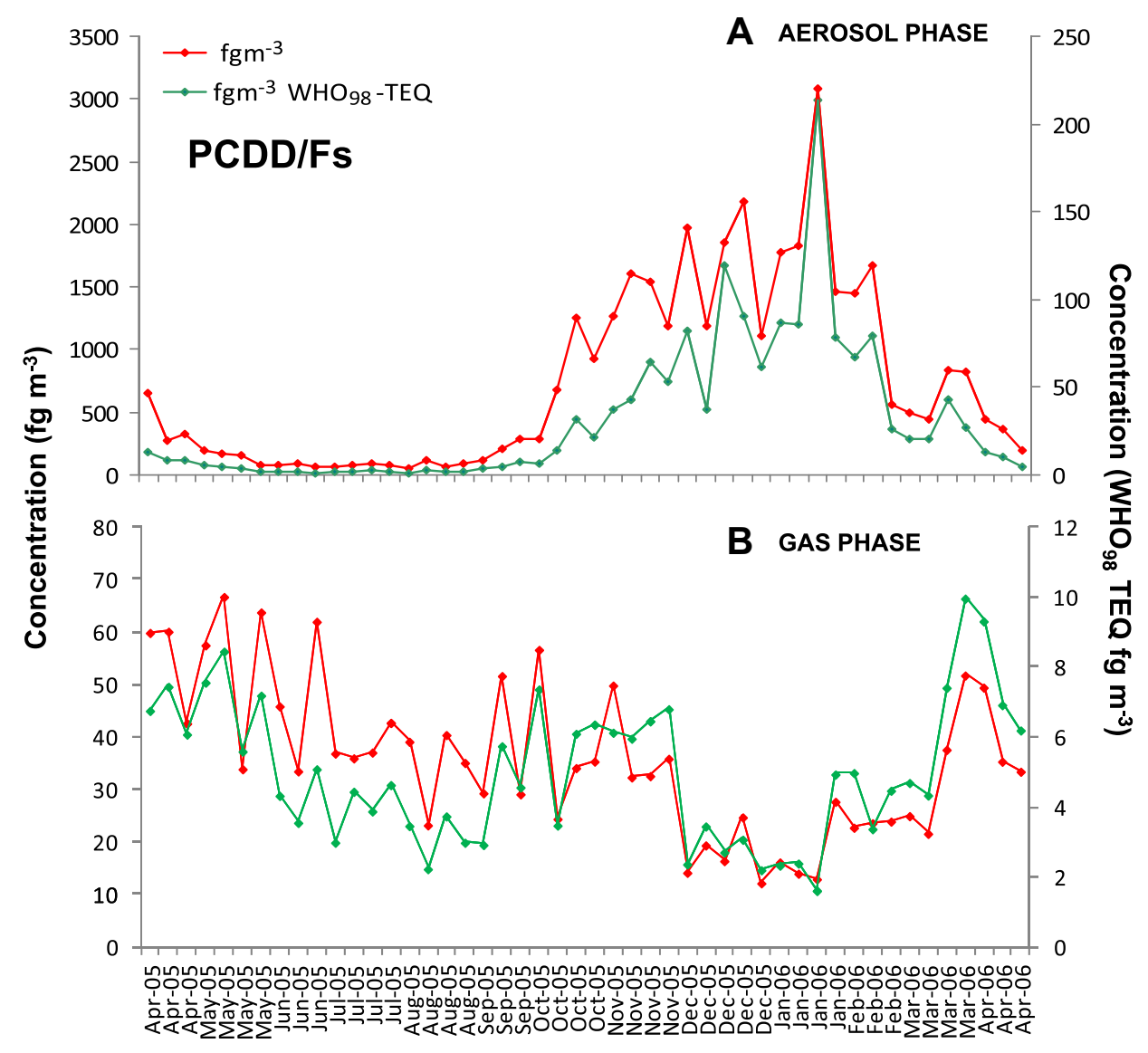

Fig. 2. Atmospheric boundary layer concentrations of aerosol and gas phase PCDD/Fs monitored in 2005-2006 in sub-alpine northern Italy.

$14 \pm 4 \%$, respectively (Fig. S2A), whereas PCB-126 (72 $\pm 7 \%$ ) and PCB-118 $(13 \pm 6)$ dominated the total DL-PCB TEQ (Fig. S2B). PCDD/ $F$ levels in sub-alpine northern Italy are within the range of those reported for rural or semi-rural areas around the world (Lohmann and Jones, 1998; Abad et al., 2004; Shih et al., 2006; Cleverly et al., 2007; Choi et al., 2008; Venier et al., 2009), whereas DL-PCB levels are within the range of those reported for residential or moderate urban/industrial areas (Choi et al., 2008, Martínez et al., 2010; Castro-Jiménez et al., 2011).

$\sum 2,3,7,8-\mathrm{PCDD} / \mathrm{F}$ and $\sum \mathrm{DL}-\mathrm{PCBs}$ aerosol phase concentrations were higher from October 2005 to February/March 2006. Concentrations peaked in the coldest months of winter, in particular in January 2006 when the highest concentrations were measured (Figs. 2 and 3A). These concentration peaks reflect the unusually high $\mathrm{PM}_{2.5}$ values (up to $120 \mathrm{ug} \mathrm{m}^{-3}$ ) registered at the EMEP Ispra station during the period 17-24 January, corresponding with the third integrated sample of the month (Table S1, SM). The seasonal trend was especially marked for dioxins. The aerosol-bound DLPCBs, although not dominating total (gas + aerosol) atmospheric levels, exhibited a very similar trend to the aerosol-bound PCDD/Fs. Higher PCDD/F concentrations in winter are reported elsewhere and have been attributed to a lower atmospheric mixing height (less favoring dispersion of local emissions) and the increase of household wood burning for heating in the cold period (Lohmann and Jones, 1998; Lee et al., 1999; Coutinho et al., 2007). Horizontal and vertical dispersion of pollutants emitted in northern Italy are hindered by low wind speeds (daily mean values around $1 \mathrm{~ms}^{-1}$ ) and frequent inversion layers near ground with fog episodes in the cold season (Rodríguez et al., 2005). Moreover, yearly wood consumption of 1.57 million tons for residential heating has been estimated for the region of Lombardy (Pastorello et al., 2011).

PCDD/F and DL-PCB gas phase concentrations also exhibited a seasonal trend. However, dioxin-like pollutant gas phase concentrations were in general higher in warmer months (spring/ summer), and lower in the coldest months (Dec-Feb 2005) (Figs. 2 and $3 \mathrm{~B}$ ). Higher $\mathrm{PCB}$ gas phase concentrations in the warmer season have been largely attributed to the increase of $\mathrm{PCB}$ volatilization rates (temperature dependent) from environmental reservoirs such as, formerly exposed soils, water, vegetation, etc. (ManchesterNeesving and Andren, 1989; Hillery et al., 1997; Simcik et al., 1997; 1999; Cousins and Jones, 1998; Wania et al., 1998). Indeed, this effect has also been observed at the same site and time period for non-DL-PCBs (Castro-Jiménez et al., 2009). PCDD/F gas phase concentrations are infrequently measured due to the fact that ambient levels are dominated by the aerosol-bound fraction as a sum of congeners (see discussion above). We have estimated that the $\sum 2,3,7,8-\mathrm{PCDD} / \mathrm{F}$ percent in the gas phase can vary from $0.5 \%$ (winter) to 39\% (summer) of the total concentration in the studied area. This share of gas phase fraction to the total atmospheric concentration may be higher for low MW PCDD/Fs, in particular for 2378-TCDD and 2378-TCDF (the most toxic ones), reaching in average up to $49 \pm 20 \%$ and $60 \pm 26 \%$ of the total $\sum 2,3,7,8-\mathrm{PCDD} / \mathrm{F}$ atmospheric concentrations, respectively (Fig. S3, SM). However, the seasonality of dioxin gas phase concentrations, very similar to gas phase PCBs, better reflects the temperature dependence of the gas-particle partitioning of the PCDD/Fs present in the atmosphere. The gas-particle partition coefficient $(K p)$ was calculated as follows: 


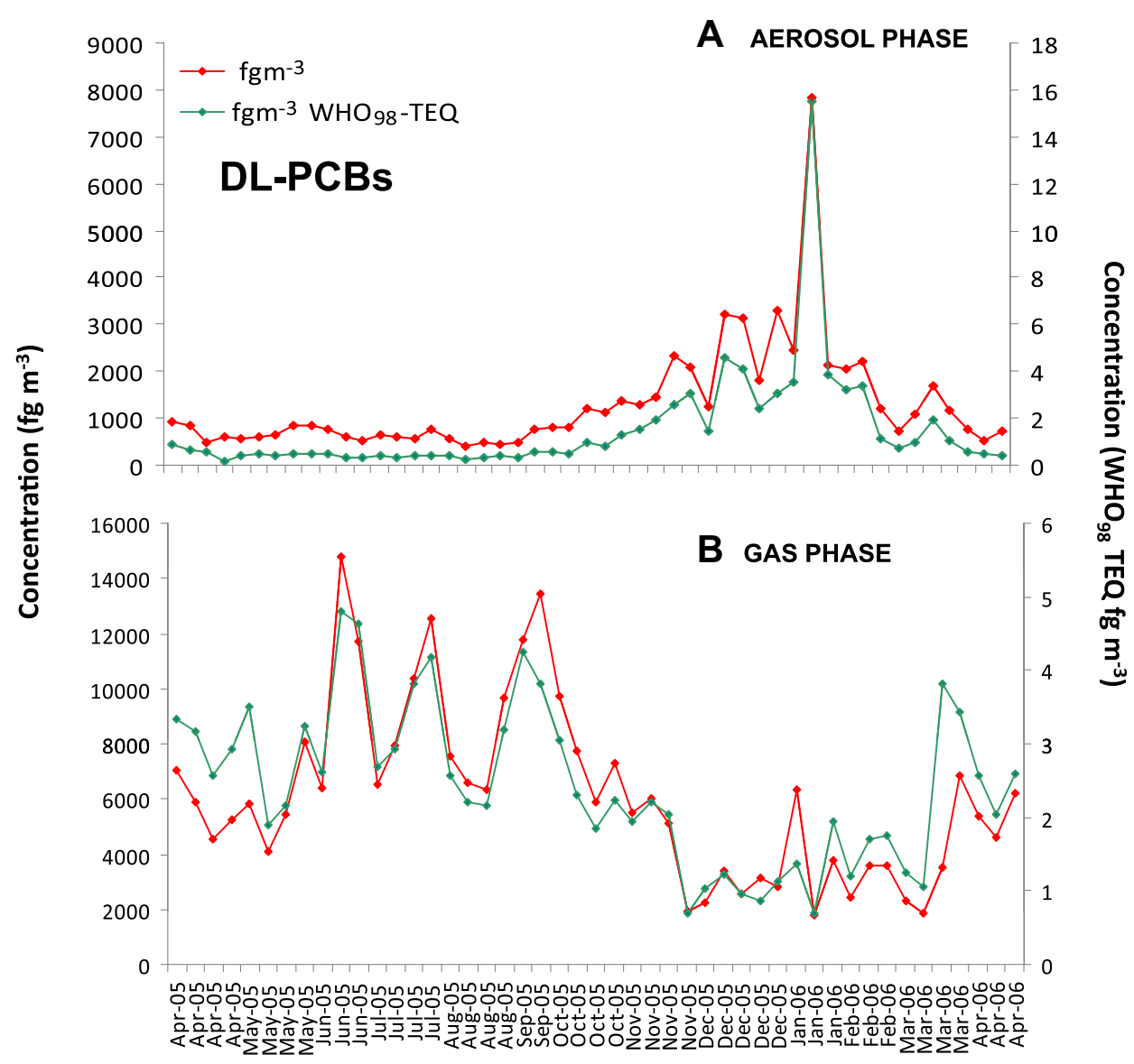

Fig. 3. Atmospheric boundary layer concentrations of aerosol and gas phase DL-PCBs monitored in 2005-2006 in sub-alpine northern Italy.

$K p=(F / \mathrm{TSP}) / \mathrm{A}$

where, $F$ and $A$ are the contaminant concentrations in the particular and gas phases, respectively $\left(\mathrm{fg} \mathrm{m}^{-3}\right)$, and TSP is the total suspended particulate matter concentration $\left(\mu \mathrm{g} \mathrm{m}^{-3}\right)$. TSP values were not available for the sampling period, therefore $P M_{10}$ annual average concentrations for $2005\left(41.2 \mu \mathrm{g} \mathrm{m} \mathrm{m}^{-3}\right)$ and 2006 $\left(32.8 \mu \mathrm{g} \mathrm{m}^{-3}\right)$ measured at the station were used instead $\left(P M_{10}\right.$ represents $\sim 75 \%$ of the TSP in the sampling site) (Castro-Jiménez et al., 2009). When plotting Ln $K p$ vs $1 / \mathrm{T}$ a significant correlation was obtained for all PCDD/F congeners (Table 1). This was also true for DL-PCBs (Table S7, SM). However, the much higher gaseous fraction of $\mathrm{PCBs}$ than $\mathrm{PCDD} / \mathrm{Fs}$ makes gas-particle partitioning unable to explain seasonality in the case of PCBs. In summary, both the aerosol and gas phase concentrations of PCDD/Fs and PCBs exhibit a very similar seasonality. Aerosol-bound dioxin-like pollutants are influenced by seasonal sources and specific meteorological conditions hindering pollutant dispersion. However, temperature is the main driver of gas phase concentrations of dioxin-like pollutants and can explain its seasonality. In the case of PCBs, temperature exerts a dominant effect by controlling the volatilization rates, while in the case of $P C D D / F$ it does by controlling the gas-particle partitioning. Indeed, the variations in the gas-particle partitioning due to changes in ambient temperature could explain between the $\sim 50-90 \%$ of the dioxin gas phase annual variability. However, potential re-volatilization of PCDD/Fs from environmental reservoirs could be also feasible even if this process appears not to be predominant. Indeed, PCDD/F volatilization from other environmental compartments such as water (Castro-Jiménez et al., 2010; Friedman et al., 2012) and soils (Schuhmacher et al., 2006; Aberg et al., 2010) have been already reported. It was not possible to asses this process with the present data set and further research is needed in this regard. This behavior may have implications for environmental exposure to dioxins, in particular in the hot season when an increase of the gas phase fraction of the most toxic congeners is likely to occur.

\subsection{Congener patterns}

PCDD/F and DL-PCB congener patterns are presented in Fig. S4 (SM). The pattern of $2,3,7,8-\mathrm{PCDD} / \mathrm{Fs}$ was dominated by the

Table 1

Temperature dependence of the gas-aerosol partition coefficient $(K p)$ for PCDD/Fs along the 1-year sampling period $(\ln K p=m(1 / T)+$ const).

\begin{tabular}{lcrlll}
\hline Dioxin congener & Slope $(m) \pm \mathrm{SE}^{\mathrm{a}}$ & Incercept $\pm \mathrm{SE}^{\mathrm{a}}$ & $n$ & $r^{2}$ & $P$ \\
\hline 2378-TCDD & $5907 \pm 952$ & $3.24 \pm 3.35$ & 47 & 0.46 & $<0.001$ \\
12378-PeCDD & $12882 \pm 960$ & $-20.45 \pm 3.38$ & 47 & 0.80 & $<0.001$ \\
$123478-H x C D D$ & $17218 \pm 862$ & $-34.57 \pm 3.03$ & 47 & 0.90 & $<0.001$ \\
$123678-H x C D D$ & $17910 \pm 884$ & $-36.97 \pm 3.11$ & 47 & 0.90 & $<0.001$ \\
$123789-H x C D D$ & $17977 \pm 969$ & $-36.96 \pm 3.41$ & 47 & 0.88 & $<0.001$ \\
$1234678-H p C D D$ & $17115 \pm 829$ & $-32.90 \pm 2.92$ & 47 & 0.90 & $<0.001$ \\
OCDD & $11515 \pm 838$ & $-12.41 \pm 2.95$ & 47 & 0.81 & $<0.001$ \\
2378-TCDF & $9759 \pm 850$ & $-10.82 \pm 2.99$ & 47 & 0.75 & $<0.001$ \\
$12378-P e C D F$ & $13933 \pm 998$ & $-24.79 \pm 3.51$ & 47 & 0.81 & $<0.001$ \\
$23478-P e C D F$ & $15261 \pm 918$ & $-28.92 \pm 3.23$ & 47 & 0.86 & $<0.001$ \\
$123478-H x C D F$ & $18128 \pm 871$ & $-38.26 \pm 3.06$ & 47 & 0.91 & $<0.001$ \\
$123678-H x C D F$ & $18732 \pm 915$ & $-40.31 \pm 3.22$ & 47 & 0.90 & $<0.001$ \\
$234678-H x C D F$ & $16290 \pm 731$ & $-31.38 \pm 2.57$ & 47 & 0.92 & $<0.001$ \\
$123789-H x C D F$ & $17968 \pm 1000$ & $-37.11 \pm 3.52$ & 47 & 0.88 & $<0.001$ \\
$1234678-H p C D F$ & $19192 \pm 851$ & $-40.82 \pm 2.99$ & 47 & 0.92 & $<0.001$ \\
$1234789-H p C D F$ & $15501 \pm 1200$ & $-27.25 \pm 4.22$ & 47 & 0.79 & $<0.001$ \\
OCDF & $11533 \pm 842$ & $-12.89 \pm 2.96$ & 47 & 0.81 & $<0.001$ \\
\hline
\end{tabular}

a Standard Error. 
higher chlorinated congeners, OCDD and 1234678-HpCDD accounting for the $43 \pm 7 \%$ and $15 \pm 2 \%$ of the $\sum 2,3,7,8-\mathrm{PCDD} / \mathrm{Fs}$. TCDFs, PeCDFs and OCDD dominated the homologue series pattern accounting for the $22 \pm 5 \%, 14 \pm 2 \%$ and $15 \pm 5 \%$ of the $\sum \mathrm{Cl}_{4-8} \mathrm{PCDD} /$ Fs, respectively. The DL-PCB pattern was dominated by CB-118 $(65 \pm 3 \%)$ and CB-105 (20 $\pm 1 \%)$. These patterns agree with those from this site obtained earlier (Castro-Jiménez et al., 2008) and with those reported in the atmosphere around the Great Lakes, US (Venier et al., 2009).

\subsection{Atmospheric deposition}

\subsubsection{Dry deposition}

PCDD/Fs and DL-PCB dry deposition fluxes during April 2005-2006 were estimated according to Eq. (1) and are shown in Fig. 4. Atmospheric dry deposition of $\sum D L-P C B$, ranging from 140 to $1940 \mathrm{pg} \mathrm{m}^{-2} \mathrm{~d}^{-1}$, was higher than dry deposition of $\sum 2,3,7,8$ PCDD/Fs (16-1065 pg m $\mathrm{m}^{-2}$ ). Dry deposition fluxes for individual DL-PCBs and 2,3,7,8-PCDD/Fs congeners are presented in Table S8 (SM). Deposition fluxes for both contaminant's families exhibited the same annual pattern, with higher fluxes in the cold season peaking in the month of January 2006. Due to the assumptions in the dry deposition estimations these fluxes follow the seasonality of contaminant aerosol phase concentrations.

\subsubsection{Wet deposition}

Wet deposition fluxes of $\sum$ DL-PCBs and $\sum 2,3,7,8-P C D D / F s$, estimated applying Eqs. (2)-(4), are shown in Fig. 5 (Table S9 in SM compiles the fluxes of individual congeners). Estimated fluxes varied from 2 to $4660 \mathrm{pg} \mathrm{m}^{-2} \mathrm{~d}^{-1}$ for $\sum$ DL-PCBs and from 0.2 to $3540 \mathrm{pg} \mathrm{m}^{-2} \mathrm{~d}^{-1}$ for $\sum 2,3,7,8-\mathrm{PCDD} / \mathrm{Fs}$. Similar values were observed for PCDD/F and DL-PCB in the coldest period (midOctober 2005 to March 2006), whereas in the warmer months (April-September 2005) the DL-PCB fluxes were in general higher than those of PCDD/Fs. Indeed, the average PCDD/Fs to DL-PCB ratio of wet fluxes during the cold period $(0.74 \pm 0.23)$ was significantly different ( $t$-test, $p<0.001$ ) than the corresponding ratio $(0.26 \pm 0.18)$ for the warm period. The wet deposition of particles (washed out by rain) was the dominant process accounting for the $98 \%$ and $\sim 100 \%$ of the wet deposition for $\sum 2,3,7,8-\mathrm{PCDD} / \mathrm{F}$ and $\sum$ DL-PCB, respectively being the wet deposition of gas phase negligible for both chemical classes. The seasonal fluxes reflect the variations of the aerosol-bound contaminants and the precipitation pattern (rainy in spring and autumn). The contaminant loads in all precipitation events occurring in the colder months were higher than in the warmer months for comparable precipitation rates, especially for PCDD/Fs (up to $\sim 30$ fold-times higher) (see for example fluxes from 1st sample of August 2005 and 2nd samples of February 2006, Fig. 5, Table S9). The higher pollutant loads in winter reflect the higher aerosol share occurring in the cold season respect to the warm season, especially pronounced for PCDD/Fs (Fig. S5, SM). These results are in agreement with modeling estimations made for the atmospheric deposition of PCDD/Fs in North America (Zhang et al., 2009).

\subsubsection{Total atmospheric inputs}

Total atmospheric (dry + wet) depositional fluxes of dioxin-like pollutants (2,3,7,8-PCDD/Fs + DL-PCBs) in sub-alpine northern Italy vary from 0.2 to $\sim 9.5 \mathrm{ng} \mathrm{m}^{-2} \mathrm{~d}^{-1}$. While dry deposition fluxes are higher for DL-PCBs during the whole year (Fig. 4), wet deposition of DL-PCBs are greater than fluxes of PCDD/Fs only for the warm period as indicated above (Fig. 5). The dominant input to regional terrestrial and aquatic ecosystems is wet deposition. Table 2 shows the agreement of the present estimations with experimentally measured atmospheric bulk deposition fluxes. Estimated fluxes are within the range of atmospheric bulk deposition measurements performed in March 2005 in the same site $\left(\sim 8 \mathrm{ng} \mathrm{m}^{-2} \mathrm{~d}^{-1}\right.$ for $\sum 2,3,7,8-\mathrm{PCDD} / \mathrm{Fs}+$ DL-PCBs) (Vives et al., 2007). The comparison with atmospheric bulk deposition measurements from other areas world-wide highlights the high variability of the PCDD/F atmospheric deposition fluxes in the study area (Table 2). Thus, the lower range of $\mathrm{PCDD} / \mathrm{F}$ estimated fluxes (wet + dry) in northern Italy $\left(0.02 \mathrm{ng} \mathrm{m}^{-2} \mathrm{~d}^{-1}\right)$ is comparable with the bulk deposition of PCDD/ Fs measured in various north European background sites in the last decade (Hovmand et al., 2007; McLachlan and Sellström, 2009; Bergknut et al., 2011). However, the higher end estimation of $3 \mathrm{ng} \mathrm{m} \mathrm{m}^{-2} \mathrm{~d}^{-1}$ better compares with reported bulk deposition measurements in urban areas (Halsall et al., 1997; Ogura et al., 2001). This fact is not surprising since the sampling site is characterized as rural/semi-rural area with a relative urban influence (mostly from Milan, $60 \mathrm{~km}$ to the south-east).

Lake Maggiore, the second largest lake in Italy $\left(212.5 \mathrm{~km}^{2}\right)$ exhibits a historical record of contamination by various inorganic and organic contaminants (Castro-Jiménez et al., 2008 and references there in). Due to human consumption of lake water and fish (both in Italy and Switzerland) and recreational uses of lake water,

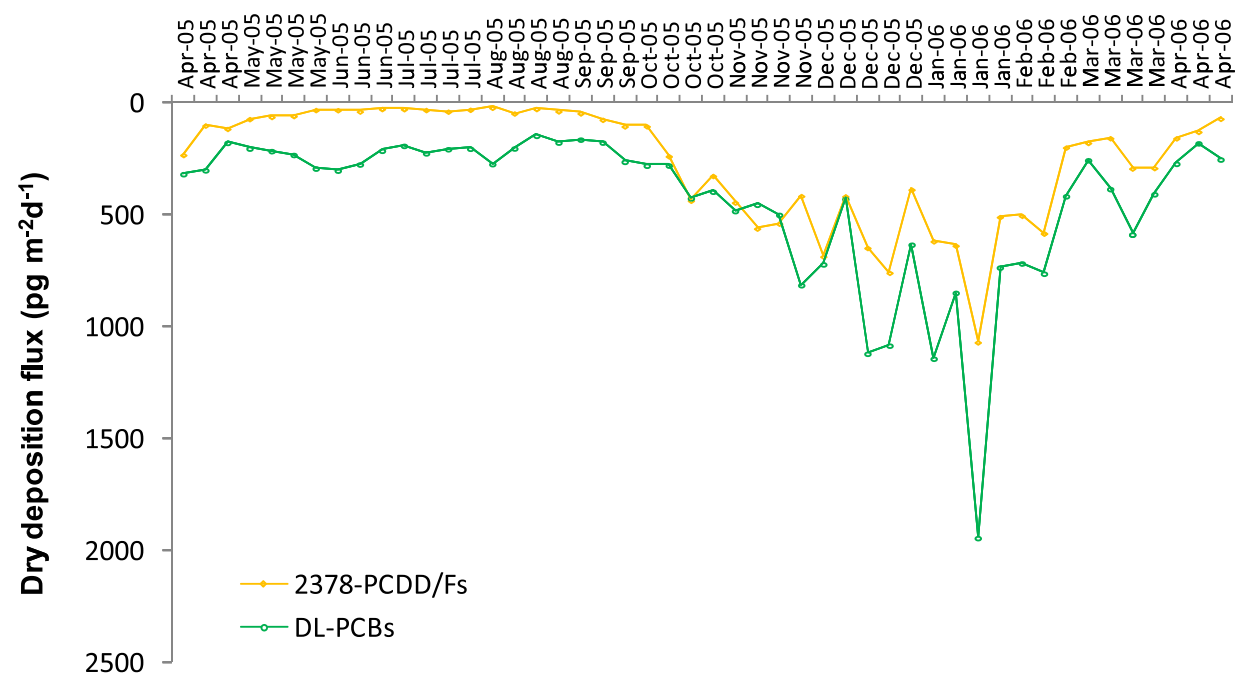

Fig. 4. $\sum 2,3,7,8-\mathrm{PCDD} / \mathrm{F}$ and $\sum \mathrm{DL}-\mathrm{PCB}$ atmospheric dry deposition fluxes ( $\mathrm{pg} \mathrm{m}^{-2} \mathrm{~d}^{-1}$ ) in sub-alpine northern Italy (2005-2006). 


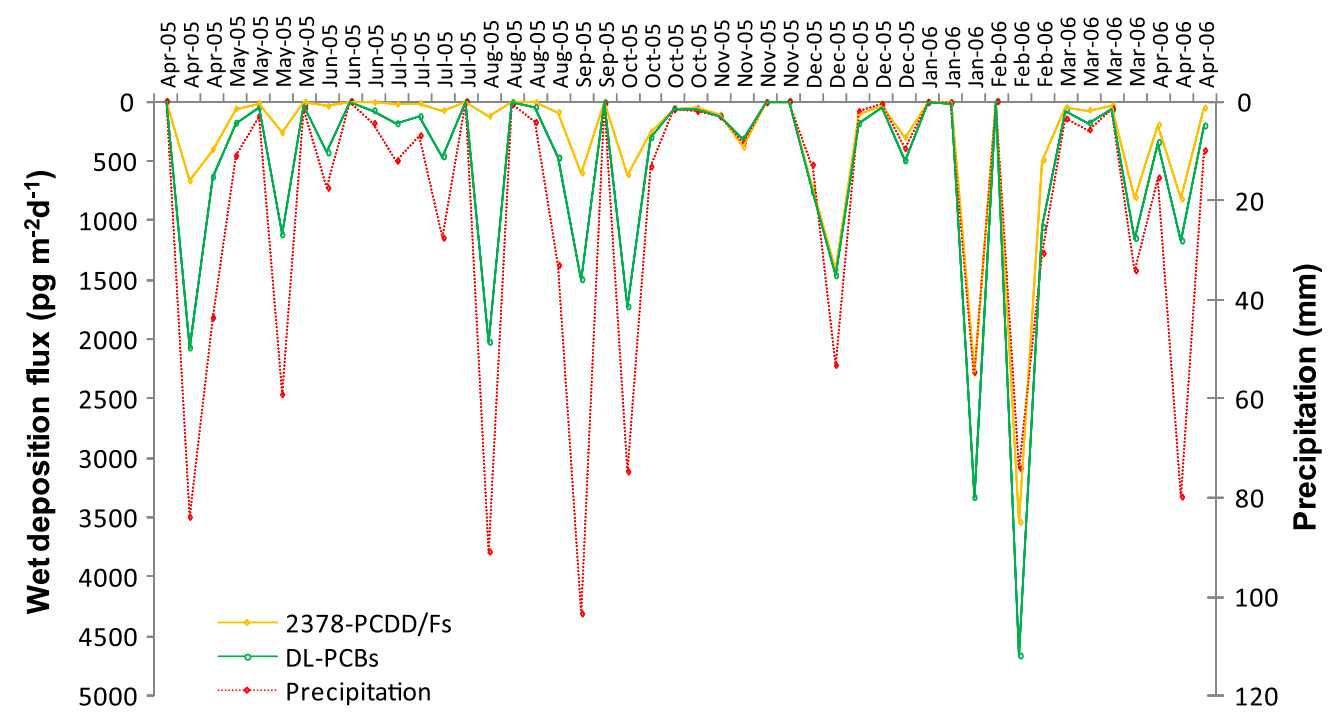

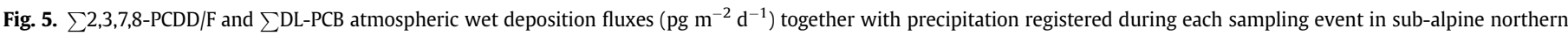
Italy (2005-2006).

Table 2

PCDD/Fs and DL-PCB measured and estimated (this study) atmospheric deposition fluxes from the literature in various sites world-wide.

\begin{tabular}{|c|c|c|c|c|c|c|}
\hline Type of flux & Type of data & $\begin{array}{l}\text { Reported flux } \\
\left(\mathrm{ng} \mathrm{m}^{-2} \mathrm{~d}^{-1}\right)\end{array}$ & Location & Site description & Study date & Reference \\
\hline Bulk deposition (PCDD/Fs + DL-PCBs) & Measured & 8 & Ispra EMEP site (Northern Italy) & Semi-reural area & Mar-05 & Vives et al., 2007 \\
\hline Bulk deposition (PCDD/Fs) & Measured & $0.01-0.1$ & Close to Stockholm (Sweden) & Background site & $2006-2007$ & $\begin{array}{l}\text { McLachlan and } \\
\text { Sellström, } 2009\end{array}$ \\
\hline Bulk deposition (PCDD/Fs) & Measured & $0.01-0.04$ & $\begin{array}{l}\text { Inlands close to Baltic sea } \\
\text { (Sweden) }\end{array}$ & Background site & $2006-2009$ & Bergknut et al., 2011 \\
\hline Bulk deposition (PCDD/Fs) & Measured & 0.07 (mean) & $\begin{array}{l}\text { Southern Scandinavia } \\
\text { (Denmark) }\end{array}$ & Background areas & $2002-2004$ & Hovmand et al., 2007 \\
\hline Bulk deposition (PCDD/Fs) & Measured & $1.2-3.6$ & Kanto Region (Japan) & Urban/semi-rural & 1996-1997 & Ogura et al., 2001 \\
\hline Bulk deposition (DL-PCBs) & Measured & $0.2-1.6$ & Kanto Region (Japan) & Urban/semi-rural & $1996-1997$ & Ogura et al., 2001 \\
\hline Bulk deposition (PCDD/Fs) & Measured & $\begin{array}{l}1.0-1.4 \\
\text { (annual mean) }\end{array}$ & Manchester and Cardiff (UK) & Urban & 1991-1992 & Halsall et al., 1997 \\
\hline Wet + dry $(\mathrm{PCDD} / \mathrm{Fs}+\mathrm{DL}-\mathrm{PCBs})$ & Estimated & $0.2-9.5$ & Ispra EMEP site (Northern Italy) & Semi-reural area & April 2005-2006 & This study \\
\hline Wet + dry $(\mathrm{PCDD} / \mathrm{Fs})$ & Estimated & $0.02-3$ & Ispra EMEP site (Northern Italy) & Semi-reural area & April 2005-2006 & This study \\
\hline Wet + dry (DL-PCBs) & Estimated & $0.2-4$ & Ispra EMEP site (Northern Italy) & Semi-reural area & April 2005-2006 & This study \\
\hline
\end{tabular}

the occurrence of toxic dioxin-like compounds should be taken into account in environmental exposure/risk assessments. A total atmospheric input $(2,3,7,8-\mathrm{PCDD} / \mathrm{Fs}+\mathrm{DL}-\mathrm{PCBs})$ ranging from 14 to $304 \mathrm{~g} \mathrm{y}^{-1}$ has been estimated for Lake Maggiore based on the calculated daily fluxes and taking into account the total number of days were rainfall was recorded $(>0.1 \mathrm{~mm})$ throughout the 1 -year sampling period. However, annual precipitation registered in 2005 and 2006 (1000-1200 mm) was in the lower end of average annual precipitation volume recorded in the Lombardy region $(1600-4000 \mathrm{~mm})$, which has one of the highest precipitation rates in Europe (European Environmental Agency, 2003). Since atmospheric loads are strongly related to the wet deposition, higher atmospheric inputs can be expected to Lake Maggiore waters and adjacent terrestrial ecosystems (including outdoor crops) if precipitation increases.

\section{Conclusions}

A comprehensive 1-year data set on aerosol and gas phase atmospheric concentrations and deposition of dioxin-like pollutants has been generated for sub-alpine northern Italy, an area where data on dioxin-like pollutants ambient levels are rare.
Environmental factors driving the total (aerosol + gas phase) atmospheric concentrations throughout the year are different for PCDD/Fs and DL-PCBs. However, when PCDD/F and DL-PCB gas and aerosol phases are examined separately, they follow a very similar seasonality. This finding provides insight on the environmental behavior of the PCDD/F and DL-PCB non-dominant fraction in the atmosphere, which is the gas phase for PCDD/Fs and the aerosol phase for DL-PCBs. Higher environmental concentrations of dioxinlike pollutants is sub-alpine northern Italy and subsequent inputs to Lake Maggiore are expected in the cold season and in rainy days due to a combined effect of the stagnant conditions, household wood burning in the area and higher pollutant burdens in rainfall in winter time. The main atmospheric exposure pathway in winter time will be contaminant particle-bound related and especially relevant for PCDD/Fs. Gas phase contaminants are expected to become more relevant in summer time, in particular the low MW dioxin congeners (i.e. the most toxic ones) and the DL-PCBs.

\section{Acknowledgements}

We would like to acknowledge A. Dell'Acqua for his support on the setting up of the sampling POPs site at the EMEP Station and to 
F. Lagler for his support with the air sampling equipment and necessary material.

\section{Appendix A. Supplementary material}

Supplementary data related to this article can be found online at doi:10.1016/j.atmosenv.2012.03.081.

\section{References}

Aas, W., Breivik, K., 2010. Heavy Metals and POPs Measurements, 2008. EMEP CCCReport 3/2010. Norwegian Institute for Air Research, 131 pp.

Abad, E., Caixach, J., Rivera, J., Gustems, L., Massagué, G., Puig, O., 2004. Temporal trends of PCDDs/PCDFs in ambient air in Catalonia (Spain). Science of the Total Environment 334-335, 279-285.

Aberg, A., Tysklind, M., Nilsson, T., MacLeod, M., Hanberg, A., Andersson, R., Bergek, S., Lindberg, R., Wiberg, K., 2010. Exposure assessment at a PCDD/F contaminated site in Sweden-field measurements of exposure media and blood serum analysis. Environmental Science and Pollution Research 17, 26-39.

Bamford, A.H., Poster, L.D., Huie, R.E., Baker, J.E., 2002. Using extrathermodynamic relationships to model the temperature dependence of Henry's Law constants of 209 PCB congeners. Environmental Science and Technology 36, 4395-4402.

Bergknut, M. Laudon, $\mathrm{H}$, Jansson, S., Larsson, A, Gocht, T, Wiberg, K, 2011. Atmospheric deposition, retention, and stream export of dioxins and PCBs in a pristine boreal catchment. Environmental Pollution 159, 1592-1598.

Blanchard, P., Audette, C.V., Hulting, M.L., Basu, H., Brice, K.A., Backsu, S.M., Dryfhout-Clark, H., Froude, F., Hites, R.A., Neilson, M., Wu, R., 2008. Atmospheric Deposition of Toxic Substances to the Great Lakes: IADN Results Through 2005 Environment Canada - U.S. EPA. ISBN: En56-156/2005E.

Breivik, K., Sweetman, A., Pacyna, J.M., Jones, K.C., 2002. Towards a global historica emission inventory for selected PCB congeners-a mass balance approach 2 . Emissions. Science of the Total Environment 290, 199-224

Bruzy, L.P., Hites, R.A., 1996. Global mass balance for polychlorinated dibenzo-pdioxins and dibenzofurans. Environmental Science and Technology 30 1797-1804.

Castro-Jiménez, J., Mariani, G., Eisenreich, S.J., Christoph, E.H., Hanke, G., Canuti, E., Skejo, H., Umlauf, G., 2008. Atmospheric input of POPs into Lake Maggiore (Northern Italy): PCDD/Fs and dioxin-like PCBs profiles and fluxes in the atmosphere and aquatic system. Chemosphere 73, S122-S130.

Castro-Jiménez, J., Dueri, S., Eisenreich, S.J., Mariani, G., Skejo, H., Umlauf, G., Zaldivar, J.M., 2009. Polychlorinated biphenyls (PCBs) in the atmosphere of subalpine northern Italy. Environmental Pollution 157, 1024-1032.

Castro-Jiménez, J., Eisenreich, S.J., Ghiani, M., Mariani, G., Skejo, H., Umlauf, G. Wollgast, J., Zaldívar, J.M., Berrojalbiz, N., Reuter, H.I., Dachs, J., 2010. Atmospheric occurrence and deposition of polychlorinated dibenzo-p-dioxins and dibenzofurans (PCDD/Fs) in the open Mediterranean Sea. Environmental Science and Technology 44, 5456-5463.

Castro-Jiménez, J., Mariani, G., Vives I., Skejo H., Umlauf G., Zaldivar J.M., Dueri S. Messiaen G., Laugier T., 2011. Atmospheric concentrations, occurrence and deposition of persistent organic pollutants (POPs) in a Mediterranean coasta site (Etang de Thau, France). Environmental Pollution 159, 1948-1956.

Choi, M.P.K., Ho, S.K.M., So, B.K.L., Cai, Z., Lau, A.K.H., Wong, M.H., 2008. PCDD/F and dioxin-like PCB in Hong Kong air in relation to their regional transport in the Pearl River Delta region. Chemosphere 71, 211-218.

Cleverly, D., Ferrario, J., Byrne, C., Riggs, K., Joseph, D., Hartford, P., 2007. A genera indication of the contemporary background levels of PCDDs, PCDFs and coplanar PCBs in the ambient air over rural and remote areas of the United States. Environmental Science and Technology 41, 1537-1544.

Colombo, A., Benfenati, E., Mariani, G., Lodi, M., Marras, R., Rotella, G., Senese, V., Fattore, E., Fanelli, R., 2009. PCDD/Fs in ambient air in north-east Italy: the role of a MSWI inside an industrial area. Chemosphere 77, 1224-1229.

Cousins, I.T., Jones, K.C., 1998. Air-soil exchange of semi-volatile organic compounds (SOCs) in the UK. Environmental Pollution 102, 105-118.

Coutinho, M., Pereira, M., Borrego, C., 2007. Monitoring of ambient air PCDD/F levels in Portugal. Chemosphere 67, 1715-1721.

Dueri, S., Marinov, D., Fiandrino, A., Tronczyński, J., José-Manuel Zaldívar, J.-M. 2010. Implementation of a 3D coupled hydrodynamic and contaminant fate model for PCDD/Fs in Thau Lagoon (France): the importance of atmospheric sources of contamination. International Journal of Environmental Research and Public Health 7, 1467-1485.

European Environmental Agency, 2003. Europe's Water: An Indicator-based Assessment, Topic report No 1/2003, 99 pp. http://www.eea.europa.eu/.

Fattore, E., Di Guardo, A., Mariani, G., Guzzi, A., Benfenati, E., Fanelli, R., 2003. Polychlorinated dibenzo-p-dioxins and dibenzofurans in the air of Seveso, Italy, 26 years after the explosion. Environmental Science and Technology 37, 1503-1508.

Friedman, C.L., Cantwell, M.G., Lohmann, R., 2012. Passive sampling provides evidence for newwark bay as a source of polychlorinated dibenzo-p-dioxins and furans to the New York/New Jersey, USA, atmosphere. Environmental Toxicology and Chemistry 31, 253-261.

Gioia, R., Sweetman, A., Jones, K.C., 2009. Annual Report for 2009 on the UK Toxic Organic Micro-pollutants (TOMPs) Air Monitoring and Analysis
Network. The Lancaster Environmental Center, Lancaster University, Lancaster LA1 4YQ, $41 \mathrm{pp}$

Halsall, C.J., Coeleman, P.J., Jones, K.C., 1997. Atmospheric deposition of polychlorinated debenzo-p-dioxins/dibenzofurans (PCDD/Fs) and polycyclic aromatic hydrocarbons (PAHs) in two UK cities. Chemosphere 35, 1919-1931.

Harrad, S.J., Jones, K.C., 1992. A source inventory and budget for chlorinated dioxins and furans in the United Kingdom environment. Science of the Total Environment 126, 89-107.

Hillery, B.R., Basu, I., Sweet, C.W., Hites, R.A., 1997. Temporal and spatial trends in a long-term study of gas-phase PCB concentrations near the Great Lakes. Environmental Science and Technology 31, 1811-1816.

Hovmand, M.F., Vikelsøe, J., Andersen, H.V., 2007. Atmospheric bulk deposition of dioxin and furans to Danish background areas. Atmospheric Environment 41, 2400-2411.

Hung, H., Kallenborn, R., Breivik, K., Su, Y., Brorström-Lundén, E., Olafsdottir, K., Thorlacius, J.M., Leppänen, S., Bossi, R., Skov, H., Manø, S., Patton, G.W., Stern, G., Sverko, E., Fellin, P., 2010. Atmospheric monitoring of organic pollutants in the Arctic under the Arctic monitoring and assessment Programme (AMAP): 1993-2006. Science of the Total Environment 408, 2854-2873.

Jurado, E., Jaward, F., Lohmann, R., Jones, K.C., Simo, R., Dachs, J., 2005. Wet deposition of persistent organic pollutants to the global oceans. Environmental Science. and Technology 39, 2426-2435.

Lee, R.G.M., Green, N.J.L., Lohmann, R., Jones, K., 1999. Seasonal, anthropogenic, air mass, and meteorological influences on the atmospheric concentrations of polychlorinated dibenzo-p-dioxins and dibenzofurans (PCDD/Fs): evidence for the importance of diffuse combustion sources. Environmental Science and Technology 33, 2864-2871.

Lohmann, R., Jones, K.C., 1998. Dioxins and furans in air and deposition: a review of levels, behavior and processes. Science of the Total Environment 219, 53-81.

Lohmann, R. Green, N.J.L., Jones, K.C., 1999. Atmospheric transport of polychlorinated debenzo-p-diuoxins and dibenzofurans (PCCD/Fs) in air masses across the United Kingdom and Ireland: evidence of emissions and depletions. Environmental Science and Technology 33, 2872-2878.

Lohmann, R., Breivik, K., Dachs, J., Muir, D., 2007. Global fate of POPs: current and future research directions. Environmental Pollution 150, 150-165.

Manchester-Neesving, J.B., Andren, A.W., 1989. Seasonal variation in the atmosphere concentration of polychlorinated biphenyls congeners. Environmental Science and Technology 23, 1138-1148.

Martínez, K., Austrui, J.R., Jover, E., Manuela, A., Rivera, J., Abad, E., 2010. Assessment of the emission of PCDD/Fs and dioxin-like PCBs from an industrial area over a nearby town using a selective wind direction sampling device. Environmental Pollution 158, 764-769.

McLachlan, M.S., Sellström, U., 2009. Precipitation scavenging of particle-bound contaminants - a case study of PCDD/Fs. Atmospheric Environment 43, 6084-6090.

Ogura, I., Masunaga, S., Nakanishi, J., 2001. Atmospheric deposition of poluchlorinated dibenzo-p-dioxins, and dioxin-like polychlorinated biphenyls in the Kanto Region, Japan. Chemosphere 44, 1473-1478.

Onofrio, M., Spataro, R., Botta, S., 2011. The role of a steel plant in north-west Italy to the local air concentrations of PCDD/Fs. Chemosphere 82, 708-717.

Paasivirta, J., Sinkkonen, S., Mikkelson, P., Rantio, T., Wania, F., 1999. Estimation of vapor pressures, solubilities and Henry's laws constants of selected persistent organic pollutants as functions of temperature. Chemosphere 39, 811-832.

Partzefall, W., 2002. Risk assessment of dioxin contamination in human food. Risk assessment of dioxin contamination in human food. Food and Chemical Toxicology 40, 1185-1189.

Pastorello, C., Caserini, S., Galante, S., Dilaria, P., Galleti, F., 2011. Importance of activity data for improving the residential wood combustion emission inventory at regional level. Atmospheric Environment 45, 2869-2876.

Pozo, K., Harner, T., Lee, S.C., Wania, F., Muir, D.C.G., Jones, K.C., Barrie, L., 2009. Seasonality resolved concentrations of persistent organic pollutants in the global atmosphere from the first year of the GAPS study. Environmental Science and Technology 43, 796-803.

Rodríguez, S., Van Dingenen, R., Putaud, J.-P., Dos-Santos, S.M., Roselli, D., 2005. Nucleation and growth of new particles in the rural atmosphere of Northern Italy-relationships to air quality monitoring. Atmospheric Environment 39, 6734-6746.

Safe, S., 1984. Polychlorinated biphenyls (PCBs) and polybrominated biphenyls (PBBs): biochemistry, toxicology and mechanism of action. Critical Reviews in Toxicology 13, 319-395.

Safe, S., 1990. Polychlorinated biphenyls (PCBs), dibdenzo-p-dioxins (PCDDs), dibenzofurans (PCDFs) and related compounds: environmental and mechanistic considerations which support the development of toxic equivalency factors (TEFs). Critical Reviews in Toxicology 21, 51-88.

Schottler, S.P., Eisenreich, S.J., 1997. Mass balance model to quantify Atrazine sources, transformation rates, and trends in the Great Lakes. Environmental Science and Technology 31, 2616-2625.

Schuhmacher, M., Jones, K.C., Domingo, J.L., 2006. Air-vegetation transfer of PCDD/ PCDFs: an assessment of field data and implications for modeling. Environmental Pollution 142, 143-150.

Shih, M., Lee, W.-S., Chang-Chien, G.-P., Wang, L.-C., Hung, C.-Y., Lin K-, C., 2006. Dry deposition of polychlorinated dibenzo-p-dioxins and dibenzofurans (PCDD/Fs) in ambient air. Chemosphere 62, 411-416.

Simcik, M.F. Zhang, H., Eisenreich, S.J., Franz Th., P., 1997. Urban contamination of the Chicago/Coastal Lake Michigan atmosphere by PCBs and PAHs during AEOLOS. Environmental Science and Technology 31, 2141-2147. 
Simcik, M.F., Basu, I., Sweet, C.W., Hites, R.A., 1999. Temperature dependence and temporal trends of polychlorinated biphenyl congener in the Great Lakes atmosphere. Environmental Science and Technology 33, 1991-1995.

U.S. EPA, 1994. Method 1613: Tetra-through Octa-Chlorinated Dioxins and Furans by Isotope Dilution HRGC/HRMS

U.S. Environmental Protection Agency, 1999a. Method TO-9A. Determination of polychlorinated, polybrominated and brominated/chlorinated dibenzo-pdioxins and dibenzofurans in ambient air. In: Compendium of Methods for the Determination of Toxic Organic Compounds in Ambient Air, second ed. EPA/ 625/R-96/010b, Washington, DC.

U.S. EPA, 1999b. Method 1668, Revision A: Chlorinated Biphenyl Congeners in Water, Soil, Sediment and Tissue by HRGC/HRMS.

Van den Berg, M., Birnbaum, L., Bosveld, A.T.C., Brunström B., Cook P, Feeley M.,. Giesy J.P., Hanberg A., Hasegawa R., Kennedy S.W., Kubiak T., Larsen J. C., van Leeuwen R.F.X., Djien Liem A.K., Nolt C., Peterson R.E., Poellinger L., Safe S., Schrenk D., Tillitt D., Tysklind M., Younes M., Wærn F., Zacharewski T., 1998. Toxic equivalency factors (TEFs) for PCBs, PCDDs, PCDFs for humans and wildlife. Environmental Health Perspectives 106, 775-792.
Venier, M., Ferrario, J., Hites, R.A., 2009. Polychlorinated dibenzo-p-dioxins and dibenzofurans in the atmosphere around the Great Lakes. Environmental Science and Technology 43, 1036-1041.

Vives, I., Canuti, E., Castro-Jiménez, J., Christoph, E.H., Eisenreich, S.J., Hanke, G., Huber, T., Mariani, G., Mueller, A., Skejo, H., Umlauf, G., Wollgast, J., 2007. Occurrence of polychlorinated dibenzo-p-dioxins and dibenzofurans (PCDD/Fs) polychlorinated biphenyls (PCBs) and polybrominated diphenyls ethers (PBDEs) in Lake Maggiore (Italy and Switzerland). Journal of Environmental Monitoring 9, 589-598.

Wania, F., Mackay, D., 1996. Tracking the distribution of persistent organic pollutants. Environmental Science and Technology 30, 390A-396A.

Wania, F., Haugen, J.-E., Lei, Y.D., Mackay, D., 1998. Temperature dependence of atmospheric concentrations of semivolatile organic compounds. Environmental Science and Technology 32, 1013-1021.

Zhang, B., Meng, F., Shi, C., Yang, F., Wen, D., Aronsson, J., Gbor, P.K., Sloan, J.J., 2009. Modeling the atmospheric transport and deposition of polychlorinated dibenzo-p-dioxins and dibenzofurans in North America. Atmospheric Environment $43,2204-2212$. 